$\xi=$

\title{
Efficacy of four selective Trichoderma isolates as plant growth promoters in two peanut varieties
}

\author{
M. Kamaruzzaman ${ }^{1 *}$, M. M. Rahman ${ }^{2}$, M. S. Islam ${ }^{1}$, M. U. Ahmad ${ }^{1}$ \\ ${ }^{1}$ Department of Plant Pathology, Bangladesh Agricultural University, Mymensingh-2202, Bangladesh \\ ${ }^{2}$ Biotechnology and Genetic Engineering Discipline, Khulna University, Khulna-9208, Bangladesh \\ *Corresponding author E-mail: kamaru.m@webmail.hzau.edu.cn
}

\begin{abstract}
Trichoderma species are generally used as potential bio control agents against wide range of plant pathogenic fungi and some strains are reported to produce metabolites that enhance plant growth. In the current study we evaluated the four Trichoderma isolates viz. T. harzianum $\left(\mathrm{ST}_{5}\right)$, T. viride $\left(\mathrm{ST}_{6}\right)$, T. virens $\left(\mathrm{ST}_{7}\right)$ and T. atroviride $\left(\mathrm{ST}_{9}\right)$ including a control were tested as seed treatment against to find out a potential growth-promoter of Peanut. T. harzianum $\left(\mathrm{ST}_{5}\right)$ gave maximum length and weight of shoot, weight of roots with pods, weight of pods and number of nodules per plant. T. viride $\left(\mathrm{ST}_{6}\right)$ showed higher plant growth, nodulation and yield compared to $T$. virens $\left(\mathrm{ST}_{7}\right)$ and $T$. atroviride $\left(\mathrm{ST}_{9}\right)$. Minimum growth, yield and nodulation were observed with control treatment.
\end{abstract}

Keywords: Antifungal; Growth Promoter; Peanut; Seed Treatment; Trichoderma Spp.

\section{Introduction}

Peanut (Arachis hypogaea L.) or Groundnut a major oil seed and fodder legume crop, is cultivated all over the world. Peanut is ranked $15^{\text {th }}$ among oilseed crops in the world after palm oil, soybean, rapeseed and sunflower. Oil of peanut which does not contain health deteriorating erucic acid is good for cooking purposes. It also contains the essential amino acids including cystine that are crucial for health (Orhan et al., 2011). There are many obstacles responsible for the low yield of peanut. Among them biotic factors such as light, temperature, nutrients, and microorganisms play a vital role (Oerke, 2006). Different plant pathogens significantly influence the germination ability of wide range of crop varieties. Due to infection of such plant pathogens, root system is not developed and limited nodulation occur and further growth and development of the plant is also affected (John et al., 2010). Trichoder$m a$ spp. stimulates growth of shoot, root and yield (Harman et al., 2004). The enhanced root system in peanut treated with Trichoderma spp. directly enhances the nodulation and more biological nitrogen fixation helps in the photosynthetic activity of plants (Lugtenberg et al., 2013). Thus different Trichoderma spp. helps in the growth and yield which helps in the metabolism of nodulating bacteria for leguminous plant (Verma et al., 2007; Savazzini et al., 2009; Baker, 1988). T. harzianum, a plant antagonistic fungus improves biomass production and enhances root growth (Vinale et al., 2008). Trichoderma species are widely distributed free-living fungi that are common in tropical and sub-tropical ecosystems. They have been studied for their antagonistic capacity which produce antibiotics, parasitize other soil borne pathogenic fungi (Verma et al., 2007). However, it is becoming increasingly clear that certain strains also have substantial direct influence on plant development and crop productivity (Yedidia et al., 2001).

Trichoderma species have been investigated for long time as a potential bio control agent as well as plant growth promoter (Harman, 2006; Howel, 2003).
In this present study, four selective Trichoderma isolates were evaluated for their efficacy as plant growth promoter of peanut.

\section{Material and methods}

\subsection{Collection of seeds}

Healthy mature and disease free seeds of two local peanut verities of DG-2-BARI $\left(\mathrm{V}_{1}\right)$ and JB-BARI $\left(\mathrm{V}_{2}\right)$ were collected from the Bangladesh Agricultural Research Institute (BARI), Bangladesh.

\subsection{Isolation of Trichoderma isolates}

Four Trichoderma isolates viz. T. harzianum $\left(\mathrm{ST}_{5}\right)$, T. viride $\left(\mathrm{ST}_{6}\right)$, T. virens $\left(\mathrm{ST}_{7}\right)$, T. atroviride ( $\left.\mathrm{ST}_{9}\right)$ used in this study were collected from Plant Diseases Clinic, Bangladesh Agricultural University, Mymensingh, Bangladesh (Kamaruzzaman et al., 2016). Pure cultures of the Trichoderma isolates were preserved on PDA medium at $4^{\circ} \mathrm{C}$.

\subsection{Preparation of conidia suspension}

Ten (10) days old Trichoderma isolates were used for preparation of conidia suspension. The mycelial mass with spore was washed with $15 \mathrm{ml}$ sterile distilled water and suspension was filtered through muslin cloth. After filtering the concentration of the conidial suspension was measured by using a double ruled Nabuer's haemocytometer. The spore concentration was adjusted to $10^{-5}$ per $\mathrm{ml}$ by adding sterile distilled water.

\subsection{Seed treatment with Trichoderma isolates}

Seed treatment was done with minor modification (Jegathambigai et al., 2009). Twenty seeds from each variety were taken in two separate petri dishes and T. harzianum $\left(\mathrm{ST}_{5}\right)$ were poured on re- 
spective petri dish each containing solution. Seeds were dipped in solution for 5 minutes. This process was repeated for $T$. viride ( $\left.\mathrm{ST}_{6}\right), T$. virens $\left(\mathrm{ST}_{7}\right)$ and T. atroviride $\left(\mathrm{ST}_{9}\right)$, respectively. Treated seeds were properly dried under ambient environment for 2 days.

\subsection{Soil treatment}

Sandy loam soil was collected from peanut cultivated field. Soil treatment was done by autoclave. During the autoclave, temperature and pressure was maintained at $121^{\circ} \mathrm{C}$ and $15 \mathrm{psi}$ for 30 minutes.

\subsection{Sowing of seeds}

The treated seeds were directly sown in the pot. Each pot received three healthy and uniform seeds at equal distance in the mid position. The seeds were then thinly covered with soil. The resulting plants were allowed to grow providing suitable moisture by regular watering.

\subsection{Design of experiment}

Two factors factorial experiment with two varieties and 5 treatments was conducted in Randomized Complete Block Design (RCBD). Each treatment was replicated five times. All the pots were arranged randomly.

The two factors were as follows:

\begin{tabular}{ll}
\hline Factor A: Variety & Factor B: Treatment \\
\hline & $\mathrm{T}_{0}=$ Control \\
$\mathrm{V}_{1}=$ DG-2-BARI & $\mathrm{T}_{1}=T$. harzianum $\left(\mathrm{ST}_{5}\right)$ \\
$\mathrm{V}_{2}=$ JB-BARI & $\mathrm{T}_{2}=T$. viride $\left(\mathrm{ST}_{6}\right)$ \\
& $\mathrm{T}_{3}=T$. virens $\left(\mathrm{ST}_{7}\right)$ \\
& $\mathrm{T}_{4}=T$. atroviride $\left(\mathrm{ST}_{9}\right)$ \\
\hline
\end{tabular}

\subsection{Different growth parameters studied}

After 80 days, the plants at mature stage were carefully uprooted from the pots and the following parameters were studied.

- $\quad$ Length of shoot $(\mathrm{cm})$

- Weight of shoot $(\mathrm{g})$

- Weight of roots with pods $(\mathrm{g})$

- Weight of roots (g)

- Number of nodules per plant

- Weight of pods per plant (g)

\subsubsection{Measurement of length and fresh weight of shoot}

Length of shoot was measured from the base of the stem up to the topmost leaf. The shoot portions were blotted with fine tissue paper and fresh weights were measured by electrical balance before the materials could get dried.

\subsubsection{Weight of roots with pods}

The root portions with pods of each treated plant were blotted with fine tissue paper and fresh weight was measured by electrical balance before the materials could get dried.

\subsubsection{Weight of roots}

Weight of roots of each treated plant were measured by separating the pods with electrical balance.

\subsubsection{Number of nodules per plant}

The number of nodules per plant was counted and recorded for each replicated plant

\subsubsection{Weight of pods}

Weight of pods of each replicated plant was measured by electrical balance.

\subsection{Statistical analysis of data}

All data were analyzed following standard procedures for analysis of variance (ANOVA). Differences between means were evaluated for significant level following a modified Duncan's Multiple Range Test (DMRT). Except where otherwise stated, differences referred to in the text were significant at $\mathrm{P} \geq 0.05$ level of probability.

\section{Results}

In the present study, five treatments with $T$. harzianum $\left(\mathrm{ST}_{5}\right), T$. viride $\left(\mathrm{ST}_{6}\right), T$. virens $\left(\mathrm{ST}_{7}\right), T$. atroviride $\left(\mathrm{ST}_{9}\right)$ (Figure 1) and a control were evaluated their effect on different plant growth characters e.g. Length of shoot $(\mathrm{cm})$, Weight of shoot $(\mathrm{g})$, Weight of roots with pods $(\mathrm{g})$, Weight of roots only $(\mathrm{g})$, number of nodules / plant, weight of pods/ plant (g) (Table 1, Figure 2 and Figure 3) on two varieties (DG-2-BARI, JB-BARI) of peanut.
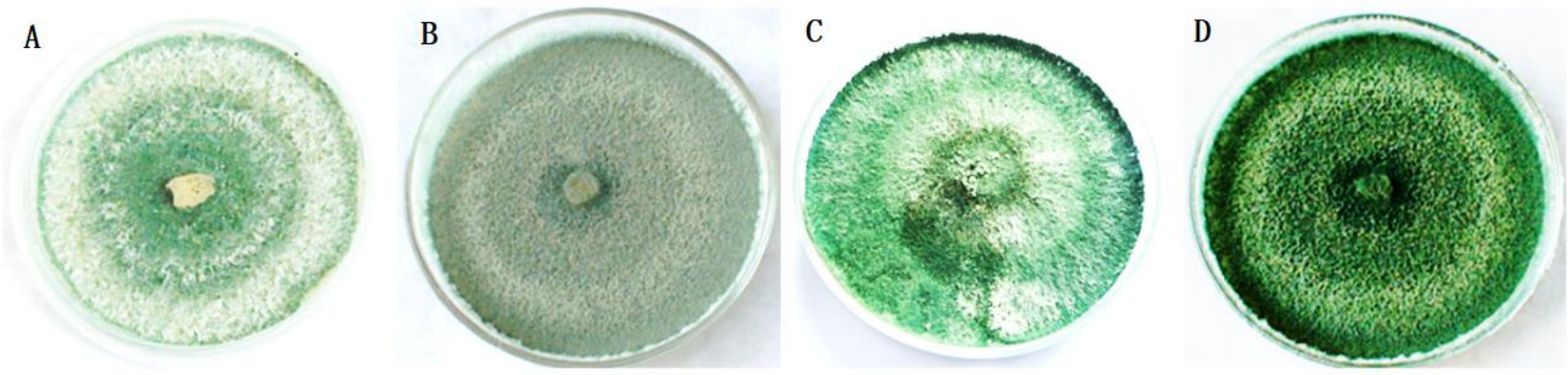

Fig. 1: Pure Culture of Trichoderma Isolates

\section{A: T. harzianum $\left(\mathrm{ST}_{5}\right)$, B: T. viride $\left(\mathrm{ST}_{6}\right), \mathrm{C}: T$. virens $\left(\mathrm{ST}_{7}\right), \mathrm{D}:$ T. atroviride $\left(\mathrm{ST}_{9}\right)$}

Table 1: Effects of Different Treatments on the Growth, Nodulation and Yield in Peanut

\begin{tabular}{|c|c|c|c|c|c|c|}
\hline Treatments & $\begin{array}{l}\text { Length of } \\
\text { shoot }(\mathrm{cm})\end{array}$ & $\begin{array}{l}\text { Wt. of } \\
\operatorname{shoot}(\mathrm{g})\end{array}$ & $\begin{array}{l}\text { Wt. of roots with } \\
\text { pods }(\mathrm{g})\end{array}$ & Wt. of roots $(\mathrm{g})$ & $\begin{array}{l}\text { No. of nodules per } \\
\text { plant }\end{array}$ & $\begin{array}{l}\text { Wt. of pods per } \\
\text { plant }(\mathrm{g})\end{array}$ \\
\hline $\mathrm{T}_{0}=$ Control & $21.84 \mathrm{~d}$ & $15.70 \mathrm{~b}$ & $9.53 \mathrm{~b}$ & $2.08 \mathrm{a}$ & $11.30 \mathrm{~b}$ & $7.46 \mathrm{~b}$ \\
\hline $\mathrm{T}_{1}=T$. harzianum $\left(\mathrm{ST}_{5}\right)$ & $33.15 \mathrm{a}$ & $28.32 \mathrm{a}$ & $16.13 \mathrm{a}$ & $3.42 \mathrm{a}$ & $14.80 \mathrm{a}$ & $12.71 \mathrm{a}$ \\
\hline $\mathrm{T}_{2}=T$. viride $\left.\left(\mathrm{ST}_{6}\right)\right)$ & $30.10 \mathrm{ab}$ & $20.46 b$ & $14.77 \mathrm{a}$ & $3.33 \mathrm{a}$ & $13.50 \mathrm{ab}$ & $12.14 \mathrm{a}$ \\
\hline $\mathrm{T}_{3}=T$. virens $\left(\mathrm{ST}_{7}\right)$ & $28.07 \mathrm{bc}$ & $18.63 \mathrm{~b}$ & $13.02 \mathrm{ab}$ & $2.98 \mathrm{a}$ & $13.20 \mathrm{ab}$ & $10.04 \mathrm{ab}$ \\
\hline $\mathrm{T}_{4}=T$. atroviride $\left(\mathrm{ST}_{9}\right)$ & $24.13 \mathrm{~cd}$ & $17.09 \mathrm{~b}$ & $10.52 \mathrm{~b}$ & $2.65 \mathrm{a}$ & $11.80 \mathrm{~b}$ & $7.870 \mathrm{~b}$ \\
\hline $\operatorname{LSD}(\mathrm{P} \geq 0.05)$ & 2.865 & 4.671 & 3.704 & NS & 2.051 & 3.252 \\
\hline
\end{tabular}




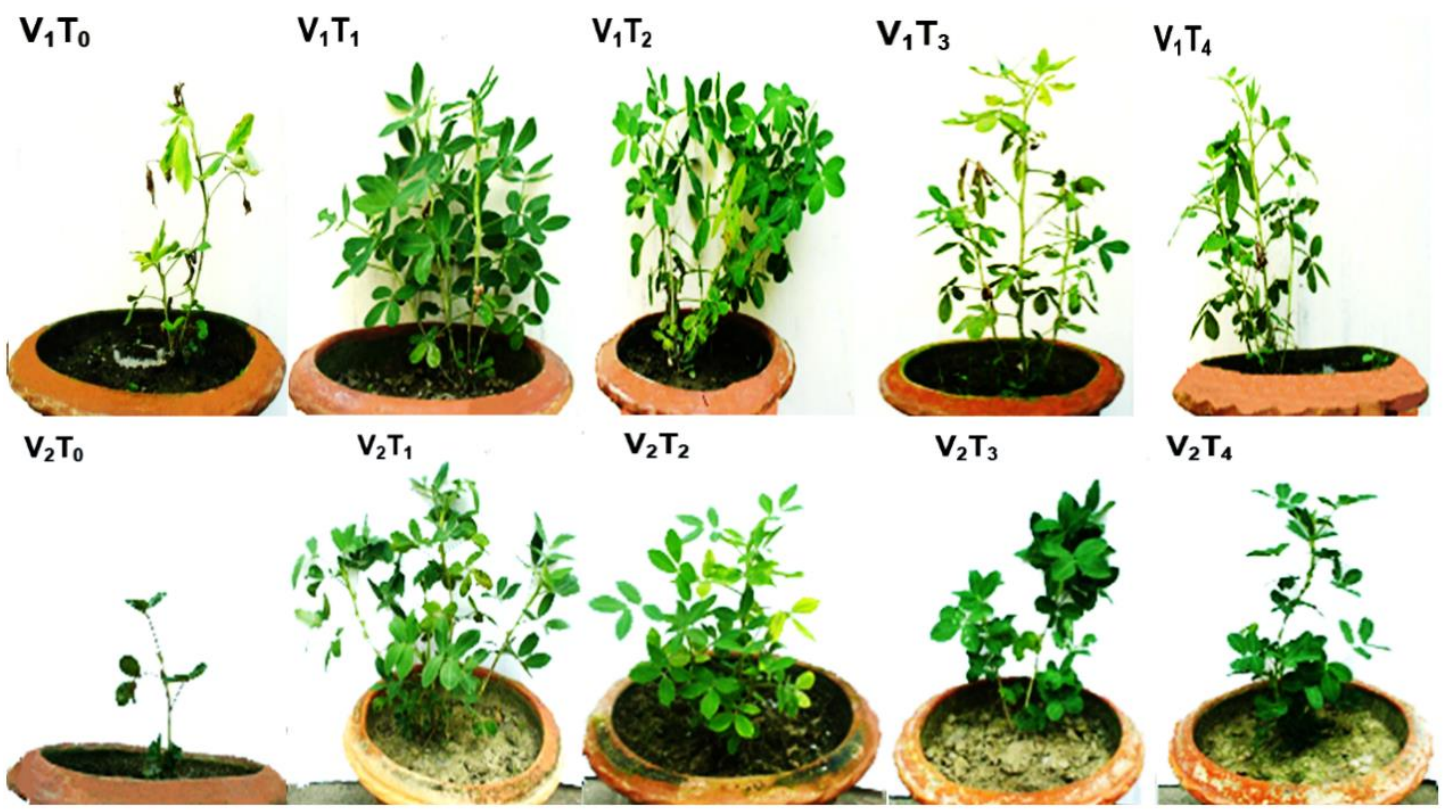

Fig. 2: Comparative Growth of Peanut Variety DG-2-BARI $\left(\mathrm{V}_{1}\right)$ And Dhaka $2\left(\mathrm{~V}_{2}\right)$ Under Treatments $\mathrm{T}_{0}, \mathrm{~T}_{1}, \mathrm{~T}_{2}, \mathrm{~T}_{3}$ and $\mathrm{T}_{4}$ after 80 Days after Plantation $\left(\mathrm{T}_{0}=\right.$ Control, $\mathrm{T}_{1}=T$. Harzianum $\left(\mathrm{ST}_{5}\right), \mathrm{T}_{2}=T$. Viride $\left(\mathrm{ST}_{6}\right), \mathrm{T}_{3}=T$. Virens $\left(\mathrm{ST}_{7}\right)$ and $\mathrm{T}_{4}=T$. Atroviride $\left.\left(\mathrm{ST}_{9}\right)\right)$

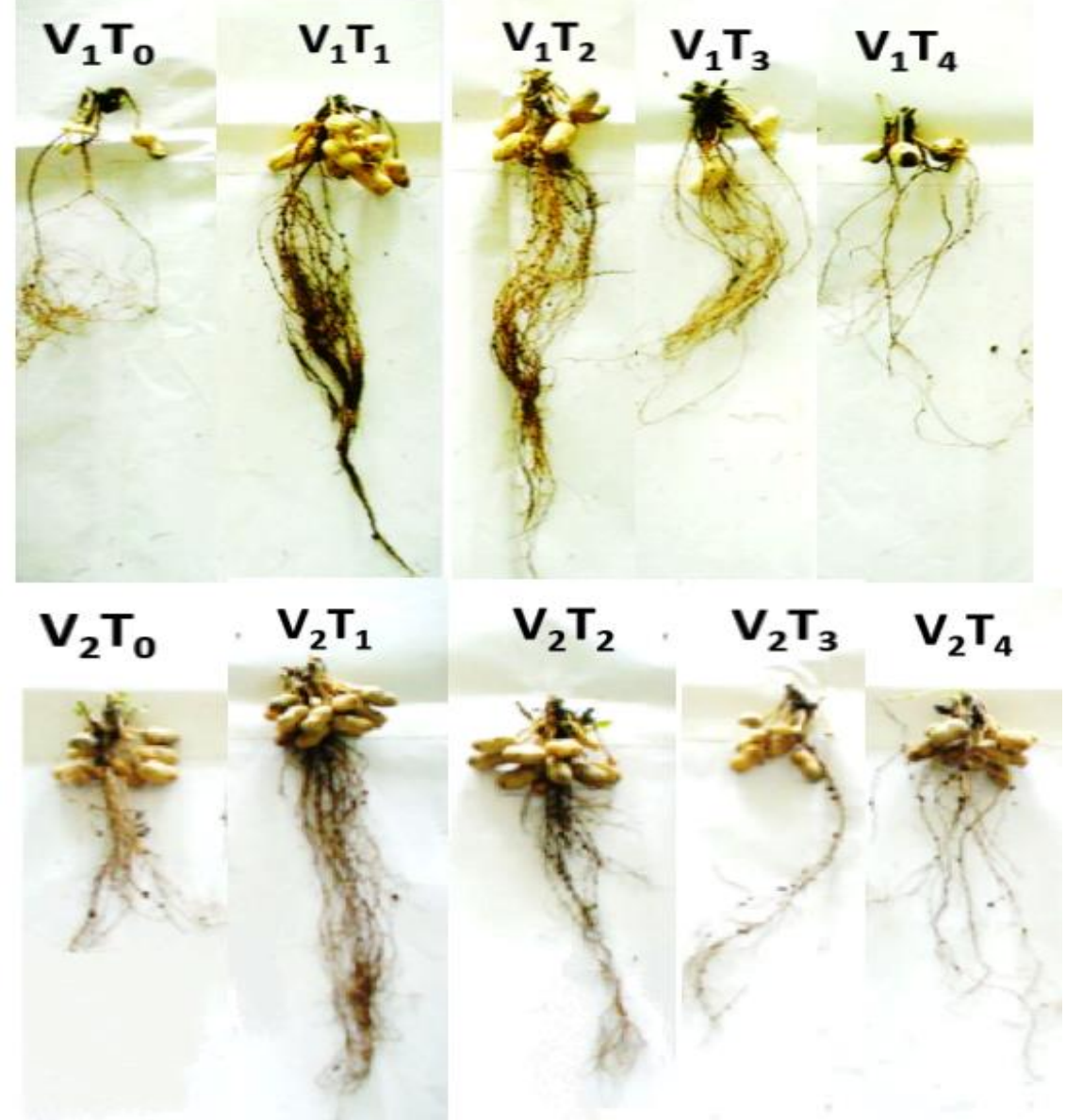

Fig. 3: Comparative Growth I.E. Pod Formation, Nodulation of Peanut Variety DG-2-BARI (V1) and Dhaka 2 (V2) Under Treatments $T_{0}, T_{1}, T_{2}, T_{3}$ and $\mathrm{T}_{4}$ after 80 Days after Plantation $\left(\mathrm{T}_{0}=\right.$ Control, $\mathrm{T}_{1}=$ T. Harzianum $\left(\mathrm{ST}_{5}\right), \mathrm{T}_{2}=$ T. Viride $\left(\mathrm{ST}_{6}\right), \mathrm{T}_{3}=T$. Virens $\left(\mathrm{ST}_{7}\right)$ and $\mathrm{T}_{4}=$ T. Atroviride $\left(\mathrm{ST}_{9}\right)$.

\subsection{Effects of different treatments on peanut}

\subsubsection{Length of shoot}

Length of shoot was significantly influenced by the treatments. The highest shoot length was recorded with treatment $\mathrm{T}_{1}=T$. har zianum $\left(\mathrm{ST}_{5}\right)$ with $33.15 \mathrm{~cm}$ followed by treatment $\mathrm{T}_{2}=$ T. viride (ST6), $\mathrm{T}_{3}=T$. virens $\left(\mathrm{ST}_{7}\right)$ and $\mathrm{T}_{4}=T$. atroviride $\left(\mathrm{ST}_{9}\right)$ with 30.10 $\mathrm{cm}, 28.07 \mathrm{~cm}$ and $24.13 \mathrm{~cm}$, respectively. Control treatment $\mathrm{T}_{0}$ appeared with the lowest shoot length $21.84 \mathrm{~cm}$.

\subsubsection{Weight of shoot}

Weight of shoot ranged from $15.70 \mathrm{~g}$ to $28.32 \mathrm{~g}$ significantly. The highest weight of shoot was recorded with the treatment $T_{1}$ with $28.32 \mathrm{~g}$ followed by lower significant and statistically identical 
weight of shoot in the treatments $\mathrm{T}_{0}, \mathrm{~T}_{2}, \mathrm{~T}_{3}$ and $\mathrm{T}_{4}$ with $15.70 \mathrm{~g}$, $20.46 \mathrm{~g}, 18.63 \mathrm{~g}$ and $17.09 \mathrm{~g}$, respectively.

\subsubsection{Weight of roots with pods}

Significantly higher and statistically identical weights of root with pods were noted with treatments $T_{1}$ and $T_{2}$ with $16.13 \mathrm{~g}$ and 14.77 $\mathrm{g}$, respectively. No significant difference was found among the treatments $\mathrm{T}_{1}, \mathrm{~T}_{2}$ and $\mathrm{T}_{3}$ with $16.13 \mathrm{~g}, 14.77 \mathrm{~g}$ and $13.01 \mathrm{~g}$, respectively. Similarly, no significant difference was found between the treatments $T_{3}$ and $T_{0}$ as well as $T_{3}$ and $T_{4}$. Lower identical response with respect to weight of roots with pods was found between $T_{0}$ and $\mathrm{T}_{4}$.

\subsubsection{Weight of roots}

The highest root weight was recorded with treatment $T_{1}$ with 3.42 $\mathrm{g}$ followed by $\mathrm{T}_{2}(3.33 \mathrm{~g})$. Identical lower response was found between the treatments $\mathrm{T}_{3}$ and $\mathrm{T}_{4}$ with $2.98 \mathrm{~g}$ and $2.65 \mathrm{~g}$, while the lowest response was found with treatment $\mathrm{T}_{0}(2.08 \mathrm{~g})$. With respect to weight of roots only no significant difference was found among the treatments.

\subsubsection{Weight of pods per plant}

Significantly higher and statistically similar weight of pods were observed with the treatments $\mathrm{T}_{1}$ and $\mathrm{T}_{2}$ with $12.71 \mathrm{~g}$ and $12.14 \mathrm{~g}$, respectively. But no significant difference was found among the treatments $\mathrm{T}_{1}, \mathrm{~T}_{2}$ and $\mathrm{T}_{3}$ with $12.71 \mathrm{~g}, 12.14 \mathrm{~g}$ and $10.04 \mathrm{~g}$, respectively. Similarly, no significant difference was found between the treatments $\mathrm{T}_{3}$ and $\mathrm{T}_{4}$ as well as $\mathrm{T}_{3}$ and $\mathrm{T}_{0}$. Lower identical response was found between the treatments $T_{0}$ and $T_{4}$ with $7.46 \mathrm{~g}$ and 7.86 g, respectively.

\subsubsection{Number of nodules per plant}

Maximum number of nodules per plant 14.80 was recorded with treatment $\mathrm{T}_{1}$ followed by $13.50,13.20,11.80$ and 11.30 nodules in the treatments $T_{2}, T_{3}, T_{4}$ and $T_{0}$, respectively. No significant difference was found among the treatments $T_{1}, T_{2}$ and $T_{3}$ with respect to number of nodules per plant. Significantly lower and identical number of nodules 11.30 and 11.80 respectively were found with the treatments $T_{0}$ and $T_{4}$. No significant difference was found among the treatments $T_{0}, T_{2}, T_{3}$ and $T_{4}$ with 11.30, 13.50, 13.20 and 11.80 , respectively.

\subsection{Responses on the different growth parameter and yield, in two peanut varieties}

Responses of the peanut varieties, DG-2-BARI $\left(\mathrm{V}_{1}\right)$ and JB-BARI $\left(V_{2}\right)$ with respect to weight of shoot and root were found to be significant. Significantly higher shoot weight and root weight respectively with $22.01 \mathrm{~g}$ and $3.68 \mathrm{~g}$ were found with the $\mathrm{JB}$ BARI $\left(\mathrm{V}_{2}\right)$ over DG-2-BARI $\left(\mathrm{V}_{1}\right)$ respectively with $18.07 \mathrm{~g}$ and 2.10 g. No significant differences were found between the two varieties in case of length of shoot, weight of roots with pods, number of pods affected with galls, number of nodules per plant, weight of pods and number of galls per plant (Table 2).

\subsection{Interaction effects of treatments and varieties of peanut on the growth nodulation and yield}

Interaction effects of the treatments and varieties on the growth, yield, nodulation and galling were found insignificant (Table 3).

Table 2: Responses on the Growth, Nodulation and Yield in Two Peanut Varieties

\begin{tabular}{|c|c|c|c|c|c|c|}
\hline Variety & $\begin{array}{l}\text { Length of } \\
\text { shoot }(\mathrm{cm})\end{array}$ & $\begin{array}{l}\text { Weight of } \\
\text { shoot }(\mathrm{g})\end{array}$ & $\begin{array}{l}\text { Weight of roots with } \\
\text { pods }(\mathrm{g})\end{array}$ & Weight of roots $(\mathrm{g})$ & $\begin{array}{l}\text { No. of nodules per } \\
\text { plant }\end{array}$ & $\begin{array}{l}\text { Wt. of pods per } \\
\text { plant }(\mathrm{g})\end{array}$ \\
\hline DG-2-BARI $\left(V_{1}\right)$ & $28.55 \mathrm{a}$ & $18.07 \mathrm{~b}$ & $11.67 \mathrm{a}$ & $2.10 \mathrm{~b}$ & $13.04 \mathrm{a}$ & $9.57 \mathrm{a}$ \\
\hline JB-BARI $\left(\mathrm{V}_{2}\right)$ & $26.37 \mathrm{a}$ & $22.01 \mathrm{a}$ & $13.91 \mathrm{a}$ & $3.68 \mathrm{a}$ & $12.80 \mathrm{a}$ & $10.52 \mathrm{a}$ \\
\hline $\operatorname{LSD}(\mathrm{P} \geq 0.05)$ & NS & 2.954 & NS & 0.9283 & NS & NS \\
\hline
\end{tabular}

Table 3: Interaction Effects of Treatments and Varieties of Peanut on the Growth, Nodulation and Yield

\begin{tabular}{lllllll}
\hline Variety & Treatment & $\begin{array}{l}\text { Length of } \\
\text { shoot }(\mathrm{cm})\end{array}$ & $\begin{array}{l}\text { Wt. of shoot } \\
(\mathrm{g})\end{array}$ & $\begin{array}{l}\text { Wt. of roots with } \\
\text { pods }(\mathrm{g})\end{array}$ & Wt. of roots $(\mathrm{g})$ & $\begin{array}{l}\text { No. of nodules per } \\
\text { plant }\end{array}$ \\
\hline & $\mathrm{T}_{0}$ & $22.35 \mathrm{a}$ & $13.70 \mathrm{a}$ & $9.12 \mathrm{a}$ & $1.70 \mathrm{a}$ & $1.45 \mathrm{a}$ \\
plant $(\mathrm{g})$
\end{tabular}

\section{Discussion}

Length of shoot, weight of shoot, weight of roots with pods, weight of roots, number of nodules per plant, weight of pods per plant were greatly influenced with the properties of bio-control agents as treatments in the peanut varieties.

Maximum length and weight of shoot, weight of roots with pods, weight of roots, weight of pods per plant and number of nodules per plant were obtained with the treatment T. harzianum (Sharma et al., 2012). Both T. harzianum and T. viride appeared with higher length of shoot, weight of roots with pods, weight of pods per plant, number of nodules per plant. Similar findings also found that $T$. harzianum gave better result in plant growth characters and yield of pods (Hoyos-Carvajal et al., 2009). No significant differences were found between $T$. viride and $T$. virens in cases of all the parameters. Similarly, no significant differences were found between the treatments $T$. virens and $T$. atroviride in most of the parameters studied. T. atroviride showed lower performance in plant growth characters, nodulation but control treatment appeared with the significant reduction in respect of growth characters, yield and nodulation. Among the treatments, T. harzianum treated plants appeared with higher growth, yield and nodulation of plants (Contreras-Cornejo et al., 2009).

Treatment with Trichoderma spp improved plant height, shoot weight, root length and weight (Shivanna et al., 1996). As a bioagent, $T$. viride increased the length of shoot as well as weight of roots with pods, number of pods per plant and number of nodules per plant correspondingly compared to the treatments $T$. virens and T. atroviride. Similar observation found that Trichoderma viride showed better performance giving higher length of shoot and root, fresh weight of root (Vestberg et al., 2004). These reports are in agreement with the present findings. The treatment with $T$. virens showed comparatively lower performance in plant growth, yield characters and nodulation. The treatment with $T$. atroviride showed lower performance in plant growth and yield characters compared to T. harzianum and $T$. viride. Identical findings observed on the interrelationship to Trichoderma spp on soybean 
(Avis et al., 2008). The effect of the organism caused significant increase in height of plant, fresh and dry weight of shoot and root, number of nodules in primary and secondary root system and nitrogen content in shoot and root. In the present study, treatment with $T$. virens and $T$. atroviride could not increase the plant growth and yield characters of peanut to the expected level.

Variety JB-BARI gave significantly higher weight of shoot and root compared to variety DG-2-BARI. Interaction effects of treatments and varities on growth and yield were found to be insignificant.

For more detailed information on the performances of the used four bio-control agent, further experiment should be carried out in pots as well as field under undisturbed experimental condition.

\section{Conclusion}

Trichoderma spp. can be a useful tool which improving the microbial community in the rhizosphere to enhance plant growth and development. In this study we found that T. harzianum $\left(\mathrm{ST}_{5}\right)$ strains could stimulate early growth in peanut plants, potentially leading to the use of these strains as novel biopromoter in agriculture with potential for increased crop yields.

\section{References}

[1] Orhan I, Özçelik B and Şener B (2011) Evaluation of antibacterial, antifungal, antiviral, and antioxidant potentials of some edible oils and their fatty acid profiles. Turkish Journal of Biology 35: 251258.

[2] Oerke E C (2006) Crop losses to pests. The Journal of Agricultural Science, 144: 31-43. http://dx.doi.org/10.1017/S0021859605005708.

[3] John R P, Tyagi R, Prévost D, Brar S K, Pouleur S and Surampalli R (2010) Mycoparasitic Trichoderma viride as a biocontrol agent against Fusarium oxysporum f. sp. adzuki and Pythium arrhenomanes and as a growth promoter of Soybean. Crop Protection 29: 1452-1459. http://dx.doi.org/10.1016/j.cropro.2010.08.004.

[4] Harman G E, Howell C R, Viterbo A, Chet I and Lorito M (2004) Trichoderma species- opportunistic, avirulent plant symbionts.

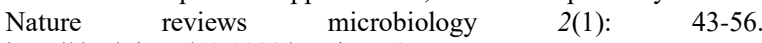
http://dx.doi.org/10.1038/nrmicro797.

[5] Lugtenberg B J, Malfanova N, Kamilova F and Berg G (2013) Plant growth promotion by microbes. Molecular microbial ecology of the rhizosphere. Wiley, Hoboken 2: 561-573. http://dx.doi.org/10.1002/9781118297674.ch53.

[6] Verma M, Brar S K, Tyagi R D, Sahai V, Prévost D, Valéro J R and Surampalli R Y (2007) Bench-scale fermentation of Trichoderma viride on wastewater sludge: rheology, lytic enzymes and biocontrol activity. Enzyme and Microbial Technology 41(6): 764-771. http://dx.doi.org/10.1016/j.enzmictec.2007.06.013.

[7] Savazzini F, Longa C M O and Pertot I (2009) Impact of the biocontrol agent Trichoderma atroviride $\mathrm{SC} 1$ on soil microbial communities of a vineyard in northern Italy. Soil biology and biochemistry $\quad 41(7)$ : 1457-1465. http://dx.doi.org/10.1016/j.soilbio.2009.03.027.

[8] Baker R (1988) Trichoderma spp. as plant-growth stimulants. CRC Crit Rev Biotechnol 7: 97-106. http://dx.doi.org/10.3109/07388558809150724.

[9] Vinale F, Sivasithamparam K, Ghisalberti E L, Marra R, Woo S L and Lorito M (2008) Trichoderma- plant- pathogen interactions. Soil Biology and Biochemistry 40(1): 1-10. http://dx.doi.org/10.1016/j.soilbio.2007.07.002.

[10] Verma M, Brar S K, Tyagi R D, Surampalli R and Valéro J R (2007) Antagonistic fungi, Trichoderma spp.: panoply of biological control. Biochemical Engineering Journal 37(1): 1-20. http://dx.doi.org/10.1016/j.bej.2007.05.012.

[11] Yedidia I, Srivastva A K, Kapulnik Y and Chet I (2001) Effect of Trichoderma harzianum on microelement concentrations and increased growth of cucumber plants. Plant and soil 235(2): 235-242. http://dx.doi.org/10.1023/A:1011990013955.

[12] Harman G E (2006) Overview of Mechanisms and Uses of Trichoderma spp. Phytopathology 96: 190-194. http://dx.doi.org/10.1094/PHYTO-96-0190.
[13] Howell C (2003) Mechanisms employed by Trichoderma species in the biological control of plant diseases: the history and evolution of $\begin{array}{llll}\text { current concepts. Plant disease 87: } & \text { 4-10. }\end{array}$ http://dx.doi.org/10.1094/PDIS.2003.87.1.4.

[14] Kamaruzzaman M, Hossain M D and Hossain I (2016) Antifungal and Morphological Assay of Selective Trichoderma Isolates Against Soil Borne Plant Pathogenic Fungi. International Journal of Innovation and Applied Studies 16(2): 409-417.

[15] Jegathambigai V, Wijeratnam R W and Wijesundera R L C (2009) Trichoderma as a seed treatment to control Helminthosporium leaf spot disease of Chrysalidocarpus lutescens. World Journal of Agricultural sciences 5: 720-728.

[16] Sharma P, Patel A N, Saini M K and Deep S (2012) Field demonstration of Trichoderma harzianum as a plant growth promoter in wheat (Triticum aestivum L). Journal of Agricultural Science, 4: 65 . http://dx.doi.org/10.5539/jas.v4n8p65.

[17] Hoyos-Carvajal L, Orduz S and Bissett J (2009) Growth stimulation in bean (Phaseolus vulgaris L.) by Trichoderma. Biological control 51: 409-416. http://dx.doi.org/10.1016/j.biocontrol.2009.07.018.

[18] Contreras-Cornejo H A, Macías-Rodríguez L, Cortés-Penagos C and López-Bucio J (2009) Trichoderma virens, a plant beneficial fungus, enhances biomass production and promotes lateral root growth through an auxin-dependent mechanism in Arabidopsis. Plant Physiology 149: 1579-1592. http://dx.doi.org/10.1104/pp.108.130369.

[19] Shivanna M B, Meera M S, Kageyama K and Hyakumachi M (1996) Growth promotion ability of zoysiagrass rhizosphere fungi in consecutive plantings of wheat and soybean. Mycoscience 37: 163-168. http://dx.doi.org/10.1007/BF02461341.

[20] Vestberg M, Kukkonen S, Saari K, Parikka P, Huttunen J, Tainio L, Devos N, Weekers F, Kevers C and Thonart P (2004) Microbial inoculation for improving the growth and health of micropropagated strawberry. Applied Soil Ecology 27: 243-258. http://dx.doi.org/10.1016/j.apsoil.2004.05.006.

[21] Avis TJ, Gravel V, Antoun H and Tweddell R J (2008) multifaceted beneficial effects of rhizosphere microorganisms on plant health and productivity. Soil Biology and Biochemistry 40: 1733-1740. http://dx.doi.org/10.1016/j.soilbio.2008.02.013. 